\title{
12. Social dialogue and world of work challenges in Romania
}

\section{Magda Volonciu}

\section{INTRODUCTION}

Romanian industrial relations have been in a state of flux since the beginning of the country's transition from socialism, which started in 1989 and has been marked, at times, by extreme ruptures. The decentralization of collective bargaining and the deep changes to tripartite social dialogue structures following the global financial crisis that engulfed Romania in 2009-10 have had negative reverberations that are still felt today. Union and employer association densities plummeted, collective bargaining coverage declined dramatically and the social partners, especially the unions, lament a weakening of the consultation and negotiation roles that social dialogue institutions had been endowed with.

Despite these negative developments, however, there are several signs of optimism. First, Romanian social dialogue institutions are well under way at the tripartite level, namely, the Tripartite National Council for Social Dialogue (Consiliul Naţional Tripartit pentru Dialog Social, CNTDS); at the bipartite-plus level, in the form of the Economic and Social Council (Consiliul Economic şi Social, CES); and at the bipartite level, with the sectoral committees (for vocational training) and joint committees (through which the social partners interpret collective contracts). Second, collective bargaining is effectively conducted at company level, although the establishment of more relaxed representativeness criteria is being sought.

Most importantly, there is rising awareness, both on the part of the social partners and of the government, of the multiple challenges facing the future world of work, represented by technological advancement, in general, and digitalization, in particular. This awareness stems from Romania experiencing an information technology (IT) boom, which has already produced tangible results: a comprehensive law on teleworking and an ambitious agreement in the banking sector to train employees to improve their digital skills, as well as several concrete proposals aimed at strengthening social dialogue.

After a brief overview of the history of industrial relations in post-socialist Romania in section 2, the chapter is structured in accordance with the three main issues raised by the social partners. Section 3 takes a thorough look at the representativeness of the trade unions and employer organizations, exploring its weaknesses and strengths, as well as possibilities for improvement. Section 4 assesses the autonomous role of the social partners when engaging in social dialogue and the mechanism's involvement in policymaking. In doing so, it presents a detailed overview of the main tripartite, bipartite-plus and bipartite social dialogue institutions in Romania, as well as the current state of affairs in collective bargaining. Section 5 explores the social partners' attitudes to digitalization 
and the platform economy, as well as the most recent development in Romania, namely, the regulation of teleworking. Section 6 presents the recent agreement in the banking sector.

\section{BRIEF HISTORY OF THE DEVELOPMENT OF LABOUR RELATIONS IN ROMANIA}

Since the beginning of the multiple transition to democracy, a market economy and European integration, Romania has experienced three periods in the development of collective labour relations: (1) a pioneering period in which the seeds of collective labour relations were planted; (2) an intermediate period of integration with European Union (EU) labour standards; and (3) a post-crisis period of decentralization and deregulation.

\subsection{The Initial Pioneering Period}

After the dramatic demise of patrimonial communism in Romania, characterized by widespread repression, material rewards for co-optation and no tolerance of dissent (Kitschelt et al. 1999), the country embarked on a long and troublesome democratic transition, which turned into democratic consolidation after the 1996 elections.

This period also coincided with the pioneering days of Romanian labour relations, which had to adapt to the nascent democratic state and the market economy. Thus, in 1991 Law No. 13/1991 on collective labour contracts (Legea nr. 13/1991 privind contractul colectiv de muncă), Law No. 15/1991 on collective labour disputes (Legea nr. 15/1991 pentru soluționarea conflictelor colective de muncă) and Law No. 54/1991 on trade unions (Legea nr. 54/1991 cu privire la sindicate) were adopted.

One of the main problems that hampered the establishment of functioning social dialogue and partnership was the underdevelopment of private enterprises, their organizations and capital-labour relations, whose role and functioning was barely understood at the beginning of the transition (even though a law on commercial companies had been passed in 1990).

Whereas the trade unions were regulated through a specific law, employer organizations were not. In 1991, Government Resolution No. 503/1991 was adopted, concerning national organizations, autonomous companies and state-owned commercial companies (Hotărârea nr. 503/1991 privind organizațiile patronale ale regiilor autonome și societăților comerciale cu capital integral de stat). Hence, only state-owned employers were regulated, which meant that the unions did not face a proper bargaining counterpart in the market. Despite this, major foundational institutions of labour relations were established during the pioneering period, none of which had existed under communist law.

\subsection{From Democratic Consolidation to the Global Financial Crisis}

The underdevelopment of employer organizations was felt during democratic consolidation and the gradual accession to the EU, completed in 2007. As Dimitriu (2019) recalls, 
new regulations replaced previously adopted laws (Law No. 13/1991 with Law No. 130/1996 on collective labour contracts, and Law No. 15/1991 with Law No. 168/1999 on resolving labour disputes).

A new Labour Code entered into force in 2003 (Legea nr. 53/2003 codul muncii). Law No. 53/2003 harmonized labour law with European regulations, introducing temporary work, apprenticeships and individualized or flexible work contracts, among other things. It also regulates the rights of employees to information and consultation, as well as providing new contractual clauses, such as clauses on non-competition or confidentiality. As for the social partners, the Law on employers No. 356/2001 (Legea patronatelor nr. 356/2001) was adopted for the first time and a new Law on trade unions No. 54/2003 (Legea sindicatelor nr. 54/2003) was also adopted.

Despite joining the EU and a relatively harmonized Labour Code, some industrial relations rules were exceptional compared with those of other member states. Dimitriu (2019) refers in this context to the erga omnes enforceability of collective labour agreements at all bargaining levels, the absence of works councils (apart from in very large undertakings at the EU level), the impossibility of imposing a lock-out and the possibility of striking legally only as a consequence of failed collective bargaining. ${ }^{1}$

\subsection{After the Crisis}

The crisis that engulfed Romania at the end of the 2000s provoked a major shift in the country's labour relations. According to Eurostat (2019a), Romanian gross domestic product (GDP) fell by 5.5 per cent in 2009 and a further 3.9 per cent in 2010. Subsequent recovery was swift, but the uncertainty as regards fiscal policy and concerns about the magnitude of the current account deficit led the international rating agencies to cut Romania's credit rating more severely than those of other emerging economies. The ten-year Romanian government bond yields crossed the symbolic 7 per cent threshold in 2007, which prompted Romania to seek a $€ 20$ billion emergency assistance package from the European Commission, the International Monetary Fund (IMF), the World Bank and other international lenders.

Drastic austerity measures were part of Romania's IMF-led agreement, which had far-reaching implications for public employment levels, pensions and other transfer payments, public-sector wage levels and other measures that impact disposable incomes and living standards. Under Article IV Consultation, the IMF held bilateral discussions with the Romanian government on economic development and policies. The consultation report focused on structural reforms and concluded that (IMF 2010, p. 26): 'Romania's labour market is rigid compared to others in the region.' 'These reforms were aimed at achieving macroeconomic stability and reducing government budget deficits, thus satisfying conditions Romania had signed up to in agreements it had made with various international financial institutions' (Chivu et al. 2013, p. xi).

Consequently, in spring 2011, the Labour Code as amended by Law No. 40/2011 and the new Law No. 62/2011 on social dialogue (Legea dialogului social nr. 62/2011) were adopted. The latter's breadth is vast, covering collective labour relations, the structures of social dialogue, aspects related to the social partners, collective conflicts and labour jurisdiction. Unlike previous labour regulations, these laws impacted the prevailing system of labour relations through greater requirements for exercising the right of association, 
increased requirements for representativeness and fundamental decentralization in collective bargaining. Even the composition of the Romanian CES, a tripartite public institution for national social dialogue between trade unions, employer organizations and the government, has been changed, through Law No. 248/2013 on the organization and functioning of the CES (Legea nr. 248/2013 privind organizarea și funcționarea Consiliului Economic și Social), which amended Law No. 62/2011.

Ever since Law No. 62/2011 came into force it has drawn recommendations from several supranational institutions involved in the assessment of their member countries' social dialogue - the European Commission EU Council and the ILO, but also Eurofound - on how to amend it in order to ensure the fuller involvement of the social partners in national policy-making.

As noted by Eurofound (2019), despite pressures to improve social dialogue, also voiced through Country-Specific Recommendations (CSRs) issued by the Council of the European Union (2018; 2019), little has changed in Romania. An important development occurred in 2017, when the social partners actively participated in the discussions of the draft for the modification of Law No. 62/2011. The consultations were carried out under the aegis of the Ministry of Social Dialogue, which was abolished in January 2018 , thereby halting a process that had been positively evaluated by the social partners themselves. Soon thereafter, in April 2018, the ILO (2018) analysed the draft law and issued several recommendations, especially concerned with definitions present in the law that deviated from international practice, starting precisely with the definition of social dialogue. Even though a new draft amendment was produced, it was not the result of concertation with the social partners.

\section{REPRESENTATIVENESS OF THE SOCIAL PARTNERS}

\subsection{Labour Unions and Employer Organizations: Establishment and Membership}

Unions are legal persons, acquiring their juridical personality by judicial means (a court grants them legal personality). According to Law No. 62/2011, trade unions can be set up by a minimum of 15 employees belonging to the same firm (previously this was possible across different firms within the same sector) and with a regular contract. The union representatives argue that these provisions limit unionization. First, atypical workers are thus barred from joining. Second, the production structure in Romania is such that there are close to half a million firms employing fewer than 15 employees, which limits the formation of trade unions. In addition, people who hold a public function, such as magistrates or the military, cannot form or join a trade union.

Union density in Romania - similar to the rest of post-socialist Europe - has been steadily declining, from 80.2 per cent in 1991, to 44 per cent in 2001 and as low as around 20 per cent in 2016 (Figure 12.1). The situation is even worse for employer organization density in the private sector, which stood at 12 per cent in 2013.

Also, in order for a trade union to be representative, it must account for at least half plus one of the employees of the company. ${ }^{2}$ If it is representative, it can negotiate collective agreements. The unions have criticized the tough requirements for representativeness, which undermine the employees' capacity to engage in collective bargaining. 


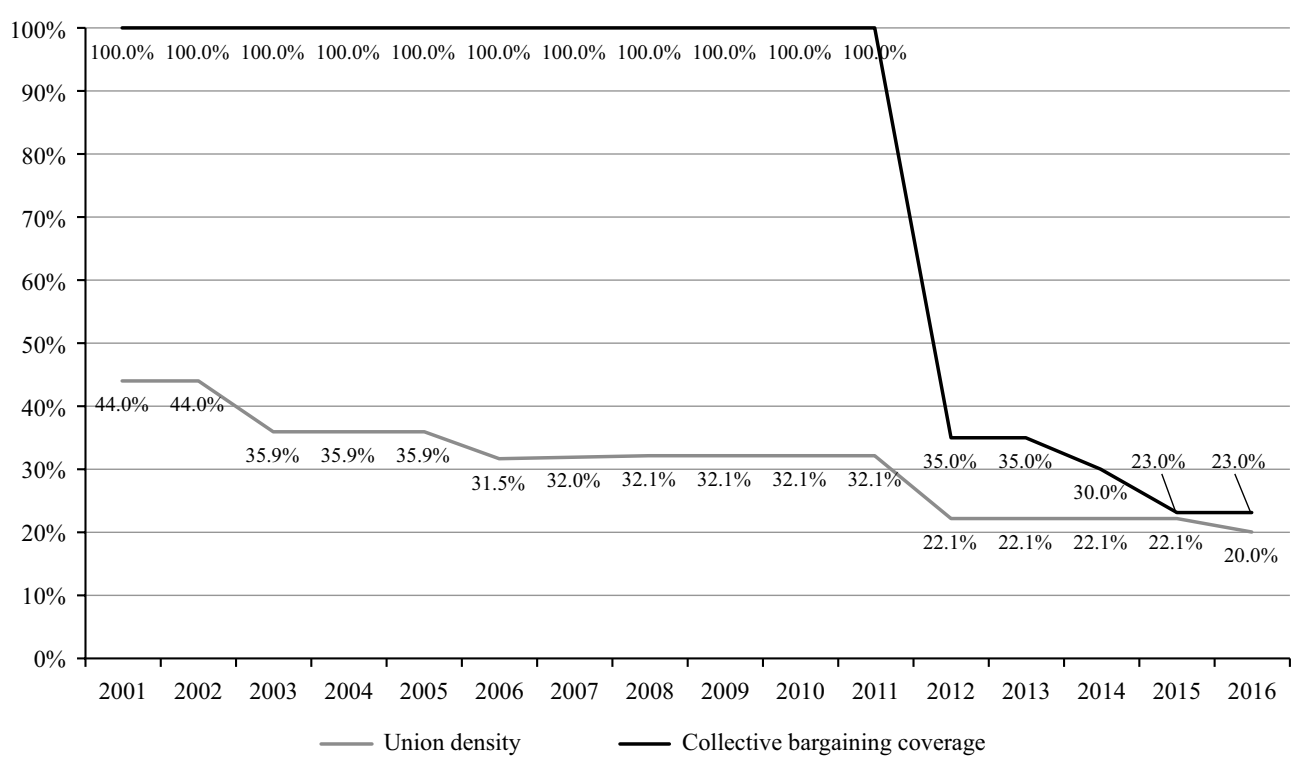

Figure 12.1 Union density and collective bargaining coverage, Romania

In their view, a threshold of 30 per cent of the total number of employees in a company (instead of half plus one) would be sufficient, thereby guaranteeing greater union pluralism.

As regards their vertical structure, unions can constitute federations (for example, at sectoral level) and confederations at the national level. Furthermore, they can also be set up at the local level (local unions, with or without legal personality). As a result of these pyramidal structures, lower-level unions table decisions that are adopted at the top. In addition, the superior structures provide the necessary support through expertise, assistance and consultancy. Similarly, employer organizations can constitute federations (for example, at the sectoral and local levels), as well as confederations at the national level.

From the standpoint of these internal structures, the unions display greater decentralization than the employers, both horizontally and vertically. This state of affairs is seen as suboptimal from both the employers' and labour's point of view. Excessive decentralization carries the risk of fragmenting the labour movement into disconnected local units. Conversely, too much centralization of employer structures creates gaps in their representativeness and leads to operational rigidity at the federation level.

The unions would hence prefer greater centralization in order to foster solidarity and closer links between different levels. The employers favour a degree of decentralization in order to be able to offer better tailored services to their members - especially in the context of technological advancements through digitalization and the spread of atypical contracts - and engage in more direct, timely, practical and principles-based bipartite dialogue. 


\subsubsection{Representativeness at the national level}

As detailed by Stoiciu et al. (2019), trade unions are deemed to be representative at the national level if the affiliated organizations account for at least 5 per cent of the employees in the national economy. Employer organizations require that their members account for at least 7 per cent of all employees in Romania. In both instances, the affiliated unions and employer organizations need to have territorial structures in at least half plus one county, including in Bucharest.

According to these criteria there are five representative unions at the national level and six employer organizations, as detailed in Table 12.1.

Neither the unions nor the employers are particularly satisfied with the representativeness criteria at the sectoral or national levels. Both criticize the establishment of these

\section{Table 12.1 List of representative unions and employer organizations, Romania}

\begin{tabular}{|c|c|c|c|}
\hline & Acronym & $\begin{array}{l}\text { Estimated } \\
\text { members }\end{array}$ & Year \\
\hline \multicolumn{4}{|l|}{ Trade unions } \\
\hline $\begin{array}{l}\text { National Confederation of Free Trade Unions } \\
\text { from Romania Frăția (Confederația Națională a } \\
\text { Sindicatelor Libere din România Frăția) }\end{array}$ & $\begin{array}{r}\text { CNSLR } \\
\text { Frăția }\end{array}$ & 306486 & 2016 \\
\hline $\begin{array}{l}\text { Meridian National Trade Union Confederation } \\
\text { (Confederația Sindicală Națională Meridian) }\end{array}$ & $\begin{array}{l}\text { CSN } \\
\text { Meridian }\end{array}$ & 264811 & 2016 \\
\hline $\begin{array}{l}\text { National Trade Union Confederation 'Cartel Alfa' } \\
\text { (Confederația Națională Sindicală 'Cartel Alfa') }\end{array}$ & $\begin{array}{l}\text { CNS Cartel } \\
\text { Alfa }\end{array}$ & 259443 & 2016 \\
\hline National Trade Union Bloc (Blocul Național Sindical) & BNS & 253227 & 2016 \\
\hline $\begin{array}{l}\text { Confederation of Democratic Trade Unions in } \\
\text { Romania (Confederația Sindicatelor Democratice } \\
\text { din România) }\end{array}$ & CSDR & 249264 & 2017 \\
\hline \multicolumn{4}{|l|}{ Employer organizations } \\
\hline $\begin{array}{l}\text { Romanian National Council of Private Small and } \\
\text { Medium-sized Enterprises (Consiliul Național } \\
\text { al Întreprinderilor Private Mici și Mijlocii din } \\
\text { România) }\end{array}$ & CNIPMMR & 327433 & 2016 \\
\hline $\begin{array}{l}\text { National Confederation of Romanian Employers } \\
\text { (Confederatia Nationala a Patronatului Roman) }\end{array}$ & CNPR & 318279 & 2015 \\
\hline $\begin{array}{l}\text { Romanian Employers Organization Confederation } \\
\text { (Confederatia Nationala a Patronatului Român) }\end{array}$ & PNR & 262519 & 2018 \\
\hline $\begin{array}{l}\text { Employers Organization from Industry, Agriculture, } \\
\text { Construction and Services of Romania } \\
\text { (Confederatia Patronala din Industrie, Agricultura, } \\
\text { Constructii si Servicii din Romania) }\end{array}$ & CONPIROM & 260412 & 2015 \\
\hline $\begin{array}{l}\text { Employers' Confederation Concordia (Confedereatia } \\
\text { Patronala Concordia) }\end{array}$ & Concordia & 230343 & 2017 \\
\hline $\begin{array}{l}\text { General Union of Romanian Industrialists (Uniunea } \\
\text { Generala a Industriasilor din România) }\end{array}$ & UGIR & 141800 & 2014 \\
\hline
\end{tabular}

Source: Stoiciu et al. (2019). 
criteria based entirely on a mathematical formula as this does not gauge the coordination efforts, effective force or commonality of espoused causes on the part of either organization. As the employers lament, obtaining representation under the conditions set out by the law sometimes results in only formal associations. Even the government authorities admit that the legal representativeness criteria are based on strictly quantitative criteria, and less on the capacity of, for example, unions to represent the interests of the employees in tripartite dialogue, thereby betraying a certain degree of formalism. However, they also claim that this formalism can be overcome through better cooperation with other organizations operating in the market, such as the chambers of commerce and industry, with the objective of improving the services offered to and defending the interests of their members.

\subsubsection{De facto representation}

Beyond the legal aspects of representation, de facto representation should be considered. Are the trade unions and employer organizations truly representative for the purpose pursued? Can these groups fully respond to the demands of those they represent? By what means will the unions and employers become representative both externally, in relation to third parties, and internally, in relation to their own members? Two main problems have been identified.

First, what is the most effective means of consolidating the position of the social partners: by law or through specific actions and dialogue? In Romania, legislation is prioritized, thereby determining the existence and functioning of the social partners. Yet, it would be beneficial in the future to base the consolidation of the social partners' mutual standing on trust and by assuming the responsibilities that come with the agreed social dialogue mechanisms. In practice, this means that the social partners should be routinely involved in consensual decision-making, whose results should be then taken into account by the government in normative acts.

Second, there is a specific problem of the obsolescence of union structures, that is, the low replacement rates among its members and leadership. Romanian society in general is affected by demographic ageing. This is even more pronounced in the case of the unions. They are not sufficiently attractive to younger members. One possible cause, identified by the unions themselves, is an education system that does not pay enough attention to the importance of introducing workers' rights in the curriculum (despite the support of the ILO).

The social partners understand the importance of attracting new members and preparing social dialogue for a changing world of work. According to one government representative:

there is a need to rethink the role of social dialogue and to support the ability to adapt representative organizations to new economic realities and to new work-related expectations. Social partners have an important role to play in providing assistance, information and training for new skills, including digital skills, for developing entrepreneurship and integrating people into traditional forms of work. The deficient protection of new types of workers also requires the intervention through regulation and control, as well as the involvement of the partners in different forms of collective bargaining, on topics of interest and with other interested/involved actors. Autonomous dialogue is essential for the efficiency and acceptance of the results of the tripartite consultation processes. 


\section{AUTONOMY OF THE SOCIAL PARTNERS}

When trying to assess the autonomy of the social partners, two approaches are possible: a subjective approach, in which the independence of the social partners is evaluated; and an objective approach, which gauges the autonomous functioning of social dialogue itself. Even though these two dimensions overlap, this section is interested in assessing the quality and independence of the social dialogue mechanisms in place, at both the tripartite and the bipartite levels.

In general, neither the social partners nor the government are entirely satisfied with the functioning of tripartite social dialogue in Romania. On the one hand, the government contends that the social partners are too passive, thereby often leaving responsibility for taking decisions to the executive. On the other hand, the employers claim that when they want to achieve a result, lobbying, especially of politicians, still ensures the greatest chance of success.

\subsection{Tripartite Social Dialogue Institutions}

Tripartite (and bipartite-plus) social dialogue institutions in Romania include: (1) the CES; (2) the CNTDS; and (3) social dialogue committees in the ministerial or local public administration (for example, county) level. ${ }^{3}$

The CES is constituted and operates on the basis of Law No. 248/2013 (Legea nr. 248/2013 privind organizarea şi funcționarea Consiliului Economic şi Social). It used to be a tripartite body, then became a bipartite-plus institution, whose predominant role is approving the normative acts affecting labour relations, social protection, wage policies, equal opportunities and treatment in the field of citizen rights, as well as in areas such as health care, education and young people, sustainable development and environmental protection. The CES prepares its own studies and analyses of socio-economic themes and events (at the request of either the government and/or the parliament, or on at its own initiative) and notifies the government and parliament in all instances and in all socioeconomic fields prescribed by the law.

The Plenum of the CES consists of 45 members, nominated as follows: (1) 15 by employer organizations representative at the national level; (2) 15 by the representative trade unions at the national level; and (3) 15 members represent civil society (appointed by the prime minister, at the proposal of the Labour Ministry) from among cooperative organizations, liberal professions, consumer protection organizations, the scientific and academic community, farmer, pensioner and local community organizations, associations that represent the family and the disabled, as well as other relevant non-governmental organizations (NGOs).

The CNTDS is the main social dialogue institution in Romania and is regulated by Law No. 62/2011 on social dialogue. It is constituted by: (1) the presidents of employer organizations and unions that are representative at the national level (six employer confederations and five trade union confederations, respectively); (2) government representatives, appointed by the prime minister, at least at the level of secretary of state, from each ministry, and from other public structures, as agreed with the social partners; and (3) a representative of the National Bank of Romania, the president of the CES and other members agreed with the social partners. 
The prime minister presides over meetings of the CNTDS. Within its premises the social partners negotiate social pacts, protocols and agreements at the national level (and monitor their implementation), they adopt resolutions on social and economic litigation through dialogue, approve extensions of collective agreements to all companies in a sector, and analyse and support the implementation of national programmes, methodological strategies and/or standards in the field of social dialogue. The CNTD provides the consultation framework in which minimum wages are determined at national level (Guardiancich and Artale 2018) and determines the sectors of activity, subsequently approved by government decision. The CNTD also actively participates in all aspects of labour relations and is entrusted with consolidating social peace through social dialogue.

The social dialogue committees are set up at the level of the ministries and counties and the municipality of Bucharest. They have a consultative role, whereby (mainly) the local administrative authority has to ensure permanent information of and consultation with the social partners on all socio-economic aspects of local and general interest. Also, the members within these structures are designated by the employer organizations and trade union confederations representative at the national level. In order to ensure a unitary working methodology and to achieve unitary policies at the national level, the activity of social dialogue committees is coordinated and supervised by the Ministry of Labour and Social Justice.

\subsubsection{Assessment of national social dialogue institutions}

The supranational institutions monitoring social dialogue have at times been critical of the functioning of tripartism in Romania. Two years in a row the Council of the European Union $(2018,2019)$ has issued CSRs within the European Semester policy cycle, which recommend that the Romanian government improve the functioning of social dialogue. In particular, the recital of the 2019 CSR states:

Beyond the collective bargaining framework, the timely and meaningful involvement of social partners on policy issues and reforms is limited. Most social dialogue takes place formally, within the CES and the Social Dialogue Committees. However, despite the established framework of dialogue and consultations, the stability and the role of these institutions has weakened over the last year. (Council of the European Union 2019, item 16)

This is echoed by Eurofound (2019), which reports that the social partners are consulted only sporadically on government policies (the executive's assessment is more positive). The CNTD hardly met in 2018 , overriding the requests of the social partners to do so. Relevant policies, such as the reforms affecting social contributions, were adopted unilaterally without due consultation and despite the social partners having a common position on the issue.

From the interviews and discussions, there is correspondence between the assessments above and the views of the social partners. Yet, the situation appears to be more nuanced. Neither the trade unions, nor the employers fully recognize the benefits of having parallel social dialogue bodies. The question arises of whether there is a need for a civic dialogue institution (the CES, in which the social partners sit alongside representatives of civil society), together with a traditional tripartite dialogue institution (the Tripartite Council). While in theory this solution is democratically sound, since civil society is called 
on to evaluate the positive or negative impacts of legal acts, in practice the CES's role is currently marginal.

The unions argue that while the social partners are well represented within the CES, the government is not, as it was substituted with civil society representatives. Also, its independence of politicians has not increased, as it is still the Labour Ministry that nominates these civil society representatives without any prior popular selection. The employers decry the excessive formalism of these tripartite institutions; the state should understand its role as a mediator rather than as a decision-maker. Too often, the social partners are called to meetings, but their views are not taken into account. During consultations on draft laws, the social partners are not given an active role in discussions; the government is only interested in checking legal requirements. Political lobbying is a more reliable way of achieving policy changes, which are decided before social dialogue begins. Finally, the government representatives claim that when the social partners do not reach consensus (often they merely express their opinions and positions), it is legitimate to exercise decision-making powers.

There are different solutions to increasing the relevance of tripartite institutions in Romania. Although no regulatory power can be conferred on these institutions, decisionmakers should be bound by the deliberations of tripartite dialogue. Also, in order for the consultation to be meaningful, a reasonable amount of time should be allowed for discussion on legislative projects.

As for the social dialogue committees, these also ensure the direct participation of the social partners in the adoption of socio-economic policies. However, the participation of the social partners in these commissions was relatively low in 2019. As shown in Table 12.2, of 131 social dialogue committee meetings at the ministerial level that took place in 2019, the union confederation that participated the most was CNS Cartel Alfa (81 meetings) and the least was CSDR (48 meetings). At the ministerial level, the Ministry of Transport organized the most meetings of social dialogue committees (33 sessions). Alongside the Ministry of Labour and Social Justice, its meetings were most popular among the unions. The participation of employer confederations in these meetings is lower than that of labour. The highest participation was registered by CONPIROM (58 meetings) and the lowest by PNR (15 meetings). The Transport Ministry and the Ministry for Public Finances elicited the highest interest.

It seems that Romanian tripartite social dialogue institutions suffer from inertia and rigidity. The government has not always adopted the best practices to ensure efficient participation of the social partners in the areas in which they are consulted (although government representatives claim that through dialogue common solutions have been found for agriculture and tourism, agreements have been reached in construction, education and schools, support has been extended to entrepreneurship and employment and apprenticeships have been introduced). Also, the social partners have not been determined enough to get their voices heard. There is a passivity among all the participating actors, which harms them and the institutions in which they interact. Tripartism is itself a balancing mechanism. Here, the state is the arbiter resolving the contradictions between the social partners, and it has a clear obligation to maintain social peace and a climate conducive to social progress. 


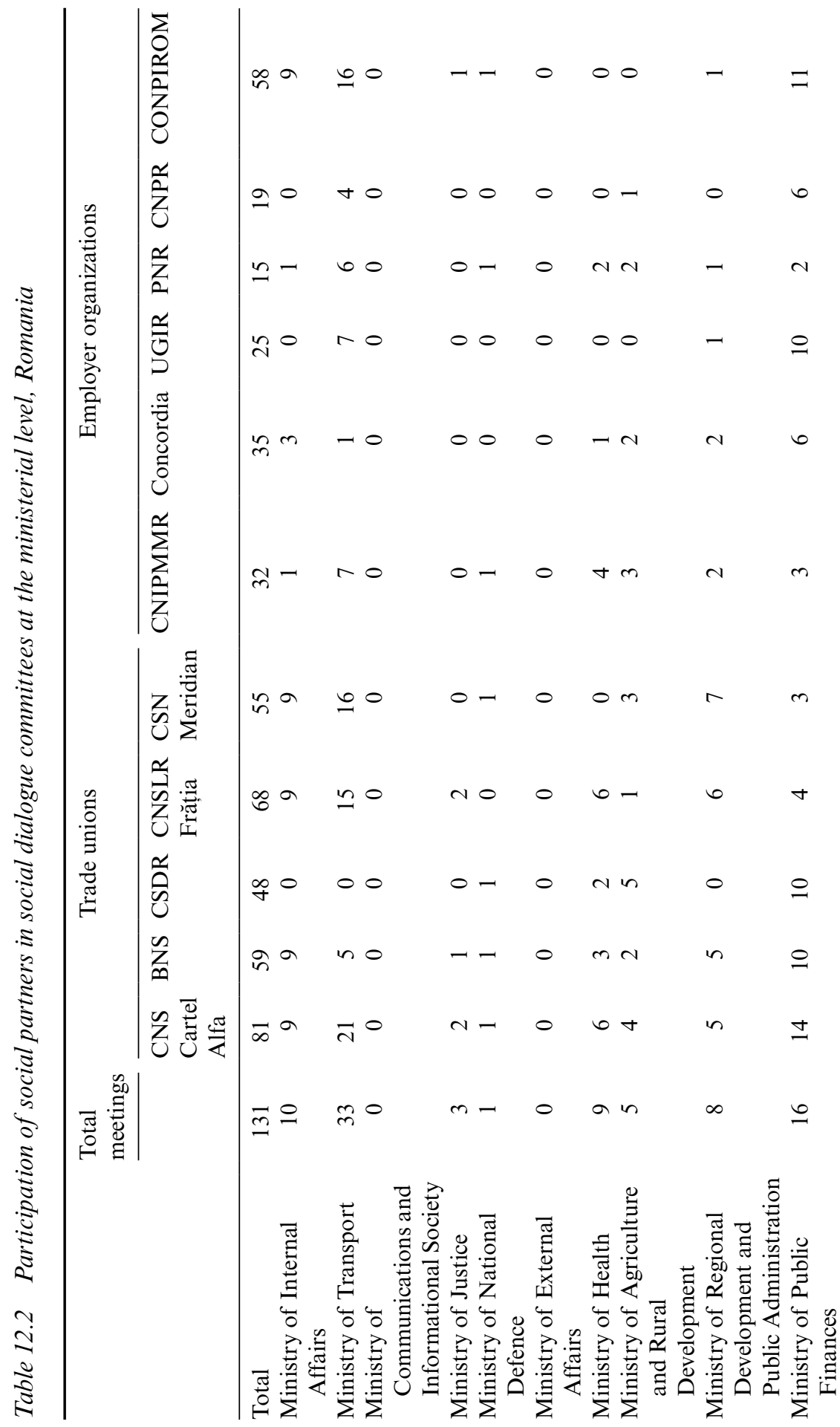




$$
\begin{aligned}
& \text { a o ont } \\
& \text { n o o- } 0 \\
& 00000 \\
& \text { in } 00-1 \\
& \text { r o htr } \\
& -0.6 \mathrm{mo} \\
& \text { o } o \text { nom } \\
& =00-0 \\
& =0 \quad n-0 \\
& n \quad 0 \quad n+0 \\
& \text { No O } \\
& =0 \text { oro }
\end{aligned}
$$

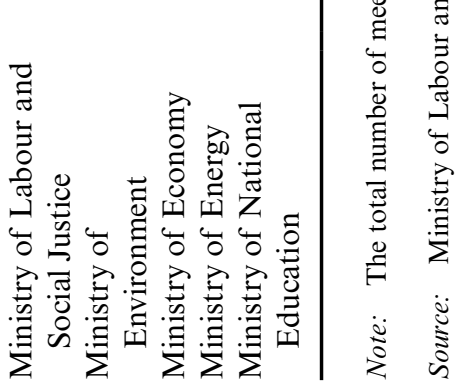




\subsection{Bipartite Social Dialogue}

Bipartite social dialogue plays a complementary role together with tripartism in Romanian industrial relations. If most institutions based on tripartism are set up and operate under the law, the majority of bipartisan bodies are the consequence of agreements between the social partners. This section covers collective bargaining (in both the private and public sectors), as well as the setup of bipartite sectoral and joint committees.

\subsubsection{Collective bargaining}

The procedures regulating collective bargaining are set out in Law No. 62/2011 on social dialogue. The aim is to conclude collective agreements covering wages and working conditions in the broadest sense, such as remuneration and introduction of new payment methods, daily and weekly work schedules, holiday arrangements, training, job security, and provisions related to informing and consulting workers (Dimitriu 2019). Collective agreements can also include clauses on personnel rights that are either more advantageous or not expressly regulated by labour legislation. Under the sanction of nullity, no clause in collective agreements can include rights below the level established by law. Under pressure from the IMF, Law No. 62/2011 abolished collective bargaining at the national level, substituted branch-level with sectoral-level bargaining and increased the importance of company-level agreements. Bargaining at firm level is compulsory for companies employing at least 21 workers (but reaching an agreement is not). ${ }^{4}$ In addition, extension mechanisms have been abolished and collective agreements only cover the companies affiliated to the signatory employer organization (bargaining at the level of a group of units). The only exception to this rule are sectoral collective agreements, signed by employers covering at least half of the sector's employees. These can be then extended to all the units in that sector by order of the Ministry of Labour and Social Justice, with the approval of the CNTD.

Post-crisis decentralization of collective bargaining had a huge impact on coverage, at three levels. First, at the end of 2010, the last national collective labour agreement, concluded for three years (2007-10) ceased to have effect and, owing to disagreement between the social partners, for the first time since 1992 it was not renewed. Second, very few sectoral collective agreements have been signed since 2011, for example, in the pre-university education sector and in health care. This level should have been of key importance, as its provisions are mandatory for all companies included in that sector of activity. However, the high thresholds in sectoral bargaining have given way to companylevel bargaining as the dominant level. Third, small enterprises in Romania with fewer than 20 employees, totalling 459000 units and employing 1.283 million workers in 2017 (Eurostat 2019b), were left entirely uncovered.

Thus, as shown in Figure 12.1, collective agreement coverage declined significantly from 100 per cent prior to 2011 to around 23 per cent in 2016, with large differences between the private and public sectors (the latest data, referring to 2013, show coverage rates of, respectively, 7.2 and 45.5 per cent; Visser 2016). According to the Labour Inspectorate, there were 7226 company-level collective agreements covering 853000 employees in 2017.

With regard to the content of collective agreements, negotiations in Romania are chiefly about wages and other pecuniary rights. In the public sector, wages and any other 
pecuniary rights are all regulated by law, hence the limitations to collective bargaining are substantial. Article 138 paragraph (1) states that agreements in the public sector 'cannot be negotiated or include clauses regarding rights in money and in kind, other than those provided by the legislation in force for the respective category of personnel', and at paragraph (3) it is stipulated that:

salary rights in the public sector are established by law within precise limits, which cannot be the object of the negotiations and cannot be modified by collective labour contracts. If wage rights are established by special laws between minimum and maximum limits, the concrete salary rights are determined by collective bargaining, but only within the legal limits.

The question is therefore legitimate: if it is not allowed to negotiate any salary rights, what is the purpose of these collective agreements? Yet most sectoral-level agreements apply to the public sector, thereby rendering the collective labour contract a mere formality. Limiting the object of negotiations so drastically seems to violate even the freedom of negotiation, the fundamental right to bargaining that is recognized also for public employees. ${ }^{5}$ Also, joint committees in the public sector are organized and operate according to the law. Their decisions are binding on the parties. In the public sector, therefore, social dialogue is required by law, while collective agreements are emptied of content.

In the pre-university education system, for example, it was possible to increase the rest days for the auxiliary and non-teaching staff through the decision of a joint committee. If collective bargaining in the public sector were not entirely hollowed out, this could have been achieved simply through traditional negotiation between the social partners, within the framework of the relevant collective agreement.

\subsubsection{Sectoral committees}

Law No. 268/2009 (Legea nr. 268/2009 pentru aprobarea Ordonanței de urgență a Guvernului nr. 28/2009 privind reglementarea unor măsuri de protecție socială) considers sectoral committees as institutions of social dialogue of public utility. These are constituted at the sectoral level on the basis of the association agreement between at least one trade union and one employer organization, both representative at the level of that sector of activity. The sectoral committees have legal personality and a special register at the Bucharest court.

The sectoral committees have several duties in relation to vocational training: they participate in the discussion of national and sectoral strategies, in establishing the normative framework in the field, and in promoting continuous professional training and occupational standards. These committees have proved their usefulness, as the social partners are interested in joint projects to be carried out within their structures. The sectoral committees, together with the Ministry of Education, elaborate the standards for professional training and are in permanent dialogue with the Ministry of Labour and Social Justice.

At the moment, according to the National Authority for Qualifications (ANC 2019), there are 16 of these sectoral committees, for: (1) construction; (2) tourism, hotels and restaurants; (3) transport; (4) health care and social assistance; (5) administrative services and support activities; (6) electricity, thermal energy, oil and gas; (7) agriculture, wood harvesting and processing, and the furniture industry; (8) the textile and 
clothing industry; (9) culture; (10) ferrous metallurgy, non-ferrous metallurgy and refractory products; (11) machine building; (12) chemicals and petro-chemicals; (13) vocational training in environmental protection; (14) agriculture, fishing and fish farming; (15) administration and public services; and (16) financial, banking and insurance activities.

Two main problems afflict sectoral committees. The committees are established at the level of branches or sectors of activity, which are now also established by normative act. As a consequence, cross-sectoral committees cannot be set up. Yet, these sectoral committees have been registered, ${ }^{6}$ which has led to tensions in the National Association of Sectoral Committees of Romania (Asociația Națională a Comitetelor Sectoriale din România). Similarly, according to the law, sectoral committees should remain bodies of social dialogue and not bodies in which third parties become involved. This has been the case, which is questionable from the viewpoint of the unions and employers. ${ }^{7}$ The employers consider that both practices exceed the existing legal framework and distort the committees' purpose of being a link between the labour market and the education system in Romania.

The government has, instead, taken a benign view; it notes that through the involvement of the social partners in the sectoral committees, they have managed to access European funds for the development of occupational standards and for increasing labour market efficiency.

\subsubsection{Joint committees}

In collective bargaining, the social partners establish joint committees, whose objective is to interpret and implement collective agreements, thereby resolving any possible misunderstandings without resorting to conflict. In practice, these committees often play only a formal role. Ambiguous clauses have to be interpreted to the employees' advantage (favourability) and this may involve high costs for the employer. The unions often press the employers to grant alternative rights, in exchange for waiving an action in court. The exceptions are larger companies, where joint committees are involved in all aspects related to the execution of a collective agreement, ${ }^{8}$ and in the public sector, where they are regulated by law. ${ }^{9}$

Other types of committee also exist. Large enterprises have set up social dialogue committees, thereby fulfilling the requirements of Directive 2002/14/EC establishing a general framework for informing and consulting employees. ${ }^{10}$ More rarely, there are joint disciplinary committees (the prerogative belongs mainly to the employer). ${ }^{11}$

According to the government, absent a willingness among the social partners to collaborate and engage in common actions, with the aim of getting involved in flexible and mutually beneficial partnerships, the authorities may impose rules in relation to association, organization, negotiation and effects of collective agreements. Here, the opinions of the social partners and of the government converge; autonomy implies active participation on behalf of all actors involved. This applies to bipartisan bodies, such as joint committees as well; they can be effective only through the continuous involvement of all parties.

The social partners agree on the need to develop bipartite dialogue, as the Law on Social Dialogue is not exhaustive. For example, joint committees are seen as functional and necessary, as they not only interpret the clauses of collective labour contracts, 
but also monitor the general applicability of contracts. ${ }^{12}$ In addition, some employer representatives have suggested that examples of good practice in social dialogue should also be part of school curricula (for example, in secondary schools).

Last but not least, in order for social dialogue mechanisms to be truly functional, adequate training of union and employer activists (not only the leadership) is necessary. This can be achieved by developing specific vocational training programmes and using socioeconomic expertise in social dialogue structures.

\section{SOCIAL DIALOGUE IN THE DIGITAL AGE}

Romania is near the forefront regarding technological advancement. Its IT sector is booming and Cluj-Napoca has been dubbed the Silicon Valley of Transylvania; in the course of a decade it has been transformed from an industrial graveyard into a technology hub boasting 1350 IT companies and 20000 developers and engineers by the end of 2018 (The Economist 2018).

According to the Employers Association of the Software and Services Industry (Asociația Patronala a Industriei de Software si Servicii; ANIS 2018), the IT market in Romania grew at an annual average rate of 12.6 per cent between 2012 and 2018 and was likely to be worth close to $€ 6$ billion by the end of 2020, employing 114000 employees with an average productivity of $€ 52500$ per year. Almost all the industry's exports in 2018 went to the EU (74 per cent) and the United States ( 22 per cent).

This IT revolution elicits both positive and negative responses from the social partners, especially in respect of the platform economy. It has triggered several legislative actions by the government - for example, a law on teleworking passed in 2018 - as well as initiatives at the bipartite level, notably through the actions of the Federation of Insurance and Banking Unions (Federatia Sindicatelor din Asigurari si Banci, FSAB).

\subsection{Legislative Action}

Even though in Romania there are still only a few flexible employment contracts, designed to fully benefit from new technologies, in 2018 the parliament passed Law No. $81 / 2018$ on the regulation of teleworking (Legea nr. 81 din 30 martie 2018 privind reglementarea activitatii de telemunca). The law laid down the condition that teleworking requires employees to perform their duties outside the employer's premises through remote communication technologies at least one day a month.

It should be noted that even before Law No. 81/2018 came into force, especially in large companies and multinationals, there was a tradition of allowing staff to work from home, usually one day a month, before the weekend. Law No. 81/2018 codified this custom, establishing the procedures, formalities and conditions to be met. Also, Romanian law regulates in detail the health and safety of teleworkers, provided that the work is performed in a location outside the employer's direct supervision and that the employer is still responsible for health and safety at work. ${ }^{13}$

Law No. 81/2018 does not differ much from similar regulations in other European states. Implementation, however, is problematic. Employers are often tempted to severely limit the locations where teleworking can take place, specifically to reduce the risks 
caused by the lack of direct supervision. Also, even if regulations exist, employers are supposed to develop precise internal norms regarding activity reporting, the work programme, and the rules of confidentiality in the case of telework, which often fail to cover all the relevant realities.

\subsection{Social Partner Attitudes}

Since the challenges posed by digitalization are diverse, here we gauge the attitudes of the social partners and government, first, in relation to the general process itself and, second, to the specific challenges posed by the emerging platform economy.

\subsubsection{Pros and cons of digitalization}

Employers tend to list several negative effects of digitalization on employees: redundancies of older workers owing to difficulties in assimilating digital skills, specific health problems related to the use of digital equipment, and the scarcity of specialized occupational training in the latest digital technologies. Among the positive effects, they argue that digital education leads to a decrease in social inequality and the creation of digital hubs for vocational training and communication, while physical work becomes easier.

As to collective labour relations, positive aspects include the fact that digital technology is cheap, fast and reduces face-to-face contact (and related emotions arising from conventional communication and negotiation). On the negative side, the ability to concentrate and assimilate information decreases, attention spans are shorter and reduced, and subdued communication limits the ability to socialize.

Two further issues were emphasized. First, the employers argue that, even under the new employment arrangements (teleworking and work on digital platforms), they exercise their authority as before, by periodically evaluating the employee's performance. Second, employers believe that digitalization in labour relations can bring down the negotiations between employee and employer to the level of the individual. This is likely to reduce the forms and instances of protest, as it would become more difficult to identify common (to workers as a group) problems.

Looking at digitalization from the trade unions' perspective, its positive effects on the individual are the possibility of working partially or totally from home, the capacity to archive documents electronically (not physically), and fast and efficient communication between people at any distance one from another. The negative aspects include the risks associated with digitalization and use of the Internet, such as exposing personal information or sensitive documents, aggressive communication, harassment and specific medical problems. Also, with the diffusion of new contractual arrangements and new forms of subordination of the employee to the employer, digitalization may increase the precariousness of work in some sectors, remove particular categories of workers from social protection and labour law, isolate and atomize the labour force, create data monopolies and over-control, while also keeping wages low through direct global competition.

Similarly, at the collective level, the use of technology for building online communities may foster connections, exchange and collaboration, as well as creating new opportunities for distance learning. On the negative front, the unions mention the atomization 
of members, their fluctuation and a decrease in the power of representation and of collective action. As for forms of protest, even if new forms of dissent emerge (online petitions are an example), street action and strikes retain the strongest impact. However, traditional forms of protest may be supported by the digital environment.

The Romanian government representatives are upbeat. According to them, digitalization may lead to the emergence of new industries creating business and employment opportunities, to greater production efficiency and to the improvement of working conditions, as well as to managerial practices that emphasize employee participation. The negative aspects should not be underplayed, though; new forms of work may be difficult to regulate, the protection of rights and representation of atypical workers is problematic owing to their lower propensity to associate, and this has a related impact on collective bargaining.

\subsubsection{Harnessing the platform economy}

The platform economy is spreading fast in Romania. Conventional employment relationships seldom apply, as individual employment contracts are substituted by civil contracts. Special rules are needed to protect these workers, and employers recognize that, although those who work on a digital platform are categorized as self-employed workers or individual companies, they have to follow the rules imposed by the platform.

Employer representatives view the workers in the platform economy from two perspectives. On the one hand, the vast majority of platform 'employees' are own-account workers (working for these platforms through their own company, which is tiny). On the other hand, they are subject to the authority of the platform's owners, who have to be held responsible for the provision of a modicum of social protection to those who work for them.

Platforms differ with regard to which aspect prevails. Uber drivers, for example, are interested in the social protection that could be provided through the platform, even if they do not consider it to be a real employer. Other platform workers, for example those providing services, such as consulting, are more concerned with the quality of what is produced and, hence, with the entrepreneurial side of their work.

Strict regulation in this context is not desirable. Generally, flexible regulations are needed to reconcile the entrepreneurial nature of some platform jobs with their social component; that is, with the basic principles of social protection. With this regulation, both the quality of the services provided and customer satisfaction would increase. In addition, by removing the traditional forms of work, the right to association is not lost. Specific new forms may emerge. For example, even within the relatively few platforms currently in operation, there are groups that interact, usually in virtual space, thereby ensuring rapid coalescence of interests and the emergence of social movements. It is possible that traditional forms of association may be less popular now mainly because in both standard and atypical employment relationships (such as through platforms for the latter) workers are less interested in organized forms of representation connected to traditional labour relations than they were in the past.

This decline has also been fostered by limitations in Romanian law. Unions can be formed only among employees of the same employer, thereby binding their existence to conventional individual employment contracts. This is outdated and should be changed. Without eliminating current practices, associations should be allowed between 
persons belonging to the same profession, independently of the worker's subordination to the same employer or the contractual relationship under which the work is carried out.

\section{CASE STUDY: COLLECTIVE AGREEMENT ON DIGITALIZATION IN THE BANKING SECTOR}

An important breakthrough in the debate on digitalization and the future of work came in the financial, banking and insurance sector, in which the social partners collaborated and have achieved some remarkable results (although they did not manage to conclude a collective employment contract at sectoral level, only at the group level).

On 18 November 2019, the Federation of Insurance and Banking Unions (FSAB), together with the Employers' Federation of Financial Services of Romania (Federatia Patronala a Serviciilor Financiare din România, FinBan) and the Council of Banking Employers of Romania (Consiliul Patronatelor Bancare din România, CPBR), signed the agreement on the professional training of employees (Acordul pentru Pregătirea Profesională a Angajaților). This is the first of this type of agreement signed between the social partners in Romania.

The agreement refers to 'collaborations between FinBan and CPBR on the one hand and FSAB on the other, as social dialogue partners in the context of the increasing needs of employees in the banking system, on the present and future challenges generated by digitalization' (CPBR 2019). The agreement involves, in practice, the setting up of an e-learning platform offering 500 courses in electronic format, of which half are available also in English. Banking employees will be able to access these courses, optionally, according to their individual interests. Courses will be available for around 25000 bank employees (out of 53000 employees at the beginning of 2019), employed by the members of CPBR. The curricula can be accessed free of charge, the costs being borne by CPBR member banks, which also provide their own platforms for project implementation. The project was to become operational in March 2020.

The agreement aims to focus on three priorities, taking into account the challenges of the digital age. These were thoroughly discussed and analysed by the social partners, who agreed to focus on the following:

1. Digital skills - aimed at more efficiently using the existing IT infrastructure and systems, in order to ensure the adaptation of the employees to digital tools, regardless of the employer. Examples of courses accessible through e-learning are personal computer (PC) literacy and reporting skills, analytical and numerical skills, digital awareness, and so on.

2. Collaboration through digital channels - aimed at acquiring and improving employees' ability to use remote working and collaboration tools, such as video conferencing, messaging, managing remote project teams.

3. The approach to customers and their satisfaction in the context of digitalization aimed at acquiring skills and competences for easier use of the tools made available by the employer from a digital perspective. 
These priorities are conceived as contributing to the development of a modern worker's skills, and not necessarily specializing in the banking sector. The broad purpose of the e-learning platform should appeal to a large number of employees. Regarding the project's success, the employer association CPBR stated that: 'We expect both our employees and our social partner, FSAB, to let us know their personal and professional satisfaction with these courses. Also, as this is to some extent an "experiment" in Romania, we hope, as employers, to see positive results.'

The agreement between FSAB, FinBan and CPBR on the professional training of employees is perceived by the social partners and the government as a tangible result of concertation and a template for serious, engaging and autonomous social dialogue.

\section{CONCLUSIONS}

The decentralization of labour relations in Romania, which followed the global financial crisis, has thus far not been fully replaced by constructive social dialogue. As the trade union representatives lament, since December 2010 no inter-sectoral collective agreement has been concluded, despite the existence of several common points of interest - on which negotiation would be needed either because there is a legislative void or because clarifications are due - often stated by the social partners themselves. This lack of real dialogue and the rigidity of current arrangements (formal and lacking a voice) have led to social conflicts in the form of strikes and spontaneous protests. These were particularly harmful to a number of employers as Romania is experiencing substantial labour shortages.

Faced with the options of stricter regulation or deregulation, the employers and the government have opted for deregulation, but also empowerment of the social partners, as a means of relaunching Romanian social dialogue. An important initiative would be to extend the reach of bipartite social dialogue to areas that are now directly subject to normative intervention. Through the routine involvement of the social partners, the government would be relieved of many tasks that could be solved directly through bipartite negotiations.

Among the measures needed to strengthen the social partners and social dialogue, some legislative changes have been extensively recommended by the European Commission and the ILO, and are favoured by all parties. In particular, the labour movement is vocal in deploring that Law No. 62/2011 has been responsible for weakening social dialogue, reducing the possibility of negotiating and concluding collective labour agreements at a higher level (above the company), and even limiting the normal exercise of union rights. Conversely, the employers do not believe that the principles on which the current legislation is based are excessively imbalanced. There are, however, problems related to the way legislation is drafted, which would require technical revisions of the normative act.

The most important development in Romania - also testified by the agreement reached in the banking sector in our case study - is that the social partners are open to real dialogue, based on good faith and reciprocity, as there is mutual understanding of the challenges ahead. It seems, also, that the government is responsive to these calls and is interested in the active cooperation of both partners, in the removal of formalism, and in the full integration of the unions and employers into the mechanisms of social dialogue. 


\section{NOTES}

1. Note that, since 2010, the National Institute of Statistics (Institutul Național de Statistică, INS) no longer reports on strikes, arguing (incorrectly) that no strikes took place between 2010 and 2017.

2. In companies with more than 20 employees, but without a trade union, the workers can be represented by employee representatives, as specified in the Labour Code. These are elected by a majority of all employees in the company (half all employees plus one), for a maximum of two years, and receive a special or general mandate. Beyond that, they cannot carry out activities entrusted by law to the unions (for example, representing in court employees who are members of a union). In company-level collective bargaining, they negotiate if there is no representative union. The labour unions are critical of employee representatives. They claim that they are often manipulated by the employer and that they do not possess the necessary knowledge or sufficient material resources and time, thereby undermining the labour movement. Furthermore, the unions estimate that up to 85 per cent of company-level collective agreements are concluded with employee representatives.

3. In addition, there are tripartite boards that deal with labour market policies, the Advisory Board of the National Agency for Employment (Agenția Națională pentru Ocuparea Forței de Muncă, ANOFM), with pensions, the Advisory Board of the National House of Public Pensions (Casa Natională de Pensii Publice, CNPP) and with health care, the National Health Insurance Agency (Casa Naționala de Asigurări de Sănătate, CNAS).

4. Law No. $1 / 2016$ amended Law No. 62/2011, thereby establishing as a rule that the representation of employees is the task of the representative union. If a union is not representative at the unit (company) level, representation is provided by the federation to which the union is affiliated, if the federation is representative at the sectoral level (to which that unit belongs). Where there is no union, representation is assured by the employees' elected representatives.

5. In Romania there have been many appeals against the decisions issued by the Court of Accounts (Curtea de Conturi a României), a government body that controls how public money is spent, trying to recover undue payments issued by public employers based on collective agreements. The decisions and appeals not only led to a large surge in the cases brought to trial, but also to contradictory jurisprudence. Ultimately, the High Court of Cassation and Justice of Romania (Înalta Curte de Casație și Justiție a României) ruled in 2016 that a right enshrined in a collective agreement must be respected, but that it also has to be compliant with the law. In so far as Romanian law puts maximum limits on to the negotiation of any rights that entail costs for the public employer, clauses resulting from negotiation that are above these limits can be nullified.

6. For example, the sectoral committee for vocational training in environmental protection refers to no specific sector of activity.

7. In the sectoral committee for financial, banking and insurance activities, there are frictions between the social partners and an educational institution that wants to be directly involved in all related professional training activities.

8. For example, joint committees determine the applicable regulations for contractual clauses related to the granting of bonuses, or the selection criteria for redundancy in the event of enterprise restructuring.

9. Resolution No. 833/2007 regarding the rules of organization and functioning of joint committees and the conclusion of collective agreements (Hotărâre nr. 833/ 2007 privind normele de organizare şi funcționare a comisiilor paritare şi încheierea acordurilor colective) ensures that social dialogue is carried out in the public sector through the participation of civil servants in the joint committees. The role of these committees is advisory and they are involved in both the professional training of civil servants and the implementation of the clauses of collective agreements at the public sector level.

10. The Directive was transposed into national law by Law No. 467/2006 establishing a general framework for informing and consulting employees (Legea nr. 467/2006 privind stabilirea cadrului general de informare și consultare a angajaților).

11. For example, when, according to the Labour Code, the employee requires in his or her defence specialized assistance through a union representative and/or a lawyer.

12. For example, by clarifying some common concepts used in collective agreements, such as salary versus income.

13. The employers claim that serious image problems can occur. Overwork and working until exhaustion are not negligible phenomena. There should be clear policies moderating the activity of employees, thereby ensuring that the rules on working time and rest are respected. At the normative level, these rules are widespread, and are the subject of EU Directives. Yet, at times, employers stretch these rules to increase productivity, and employees overwork to obtain additional monetary benefits. In an organized work environment, employers can prove that they have taken all necessary measures to protect their employees from overwork. If the employee is working remotely, the possibility of direct control on the part of employers 
is limited, but they still bear responsibility for employees' well-being. Examples of overwork in such a context abound and have been reported in the media. In these instances, not only was the health of the employee damaged, but so too was the image of the employer. The lack of direct supervision explains why in any regulation of teleworking, there are many provisions dedicated to the protection of occupational health and safety. This type of employment relationship requires not only that the employer ensures the well-being of the workers through internal norms or direct measures, but also that the employee adopts some responsibility when working outside the workspace organized by the employer.

\section{BIBLIOGRAPHY}

Asociația Patronala a Industriei de Software si Servicii (ANIS) (2018), 'Software and IT services in Romania. Current situation and outlook in a local and global environment 2018', ANIS, Bucharest.

Autoritatea Națională pentru Calificări (ANC) (2019), 'Comitete sectoriale', ANC, Bucharest, accessed September 2019 at http://www.anc.edu.ro/comitete/.

Chivu, L., C. Ciutacu, R. Dimitriu and T. Ticlea (2013), The Impact of Legislative Reforms on Industrial Relations in Romania, Geneva: International Labour Organization.

Consiliul Patronatelor Bancare din România (CPBR) (2019), 'FSAB, FinBan si CPBR semnează Acordul pentru Pregătirea Profesională a Angajaților. Bucharest: Consiliul Patronatelor Bancare din România', accessed November 2019 at https://www.cpbr.ro/stire.php?t=FSAB, $\% 20$ FinBan $\% 20$ si $\% 20$ CPBR $\% 20$ semneaza $\% 20$ Acordul $\% 20$ pentru $\% 20$ Pregatirea $\% 20$ Profesionala.

Council of the European Union (2018), Council Recommendation of 13 July 2018 on the 2018 National Reform Programme of Romania and delivering a Council opinion on the 2018 Convergence Programme of Romania (2018/C 320/22).

Council of the European Union (2019), Council Recommendation of 9 July 2019 on the 2019 National Reform Programme of Romania and delivering a Council opinion on the 2019 Convergence Programme of Romania (2019/C 301/23).

Dimitriu, R. (2019), 'Romania', in F. Hendrickx (ed.), International Encyclopaedia for Labour Law and Industrial Relations, Amsterdam: Kluwer Law Online, pp. 168-229.

Eurofound (2019), The Involvement of Social Partners in National Policymaking, Luxembourg: Publications Office of the European Union.

Eurostat (2019a), 'Real GDP growth rate - volume', accessed December 2019 at https://ec.europa. eu/eurostat/databrowser/view/tec00115/default/table?lang=en.

Eurostat (2019b), 'Annual enterprise statistics by size class for special aggregates of activities (NACE Rev. 2)', accessed December 2019 at https://ec.europa.eu/eurostat/web/structuralbusiness-statistics/data/database.

Guardiancich, I. and W.M. Artale (2018), Institutional Underpinnings of the Minimum Wage Fixing Machinery: The Role of Social Dialogue, Geneva: International Labour Organization.

International Labour Organization (ILO) (2011), Recovering from Global Crisis. SD and Adjustment in Romania: ILO Cooperation with Constituents and the IMF, GB.310/WP/SDG/2/2, Geneva: ILO.

International Labour Organization (ILO) (2018), 'Memorandum of technical comments on proposed amendments to Law 62/11 on social dialogue of Romania', ILO, Geneva.

International Monetary Fund (IMF) (2010), Staff Report for the 2010 Article 4 Consultation, Fourth Review under the Stand-by Arrangement, Country Report No. 10/227, Washington, DC: International Monetary Fund.

Kitschelt, H., Z. Mansfeldova, R. Markowski and G. Tóka (1999), Post-Communist Party Systems: Competition, Representation, and Inter-party Cooperation, Cambridge: Cambridge University Press.

Ministry of Labour and Social Justice (2019), 'Prezența partenerilor sociali la ședințele Comisiilor de Dialog Social', accessed October 2019 at http://dialogsocial.gov.ro/prezenta-cds/.

Stoiciu, V., V. Vasile, C. Boboc and S. Ghiță (2019), 'Working life in Romania', accessed October 2019 at https://www.eurofound.europa.eu/country/romania\#actors-and-institutions. 
The Economist (2018), 'Romania has a city it can boast about', The Economist, 22 December, accessed October 2019 at https://www.economist.com/europe/2018/12/22/romania-has-a-cityit-can-boast-about.

Visser, J. (2016), 'ICTWSS Database. Version 5.1' Amsterdam Institute for Advanced Labour Studies, University of Amsterdam, cited in T. Müller, K. Vandaele and J. Waddington (eds) (2018), Collective Bargaining in Europe: Towards an Endgame, vol. 4, Source Materials, Brussels: European Trade Union Institute, pp. 4, 11-12. 